\title{
Parametric Sensitivity Study of Deep Excavation in Singapore Old Alluvium Formation
}

\author{
Lanting $\mathrm{Wu},{ }^{1}$ Jianping Sun $\mathbb{D D}^{1,2}$ and Yuqiang Tong ${ }^{1}$ \\ ${ }^{1}$ China Communications Construction Company Limited (Singapore Branch), 1 Changi Business Park Central 1\#02-110, \\ Changi City, Singapore \\ ${ }^{2}$ Nanyang Technological University, 50 Nanyang Ave, Singapore \\ Correspondence should be addressed to Jianping Sun; sunj0030@e.ntu.edu.sg
}

Received 17 August 2021; Revised 5 December 2021; Accepted 6 December 2021; Published 20 December 2021

Academic Editor: Qian Chen

Copyright (C) 2021 Lanting Wu et al. This is an open access article distributed under the Creative Commons Attribution License, which permits unrestricted use, distribution, and reproduction in any medium, provided the original work is properly cited.

Deep excavation supported by vertical retaining walls together with strutting system is commonly used in Singapore for the construction of underground infrastructure. In this paper, a series of numerical scenarios simulated by PLAXIS software are carried out to study the influence of different design parameters such as pre-auger loosening effect, the embedded depth of retaining wall into the stiff soil layer, and the elastic modulus of the ground improvement layer on excavation design especially on strut force, retaining wall deflection, and bending moment. The results show that there is high risk if only a single set of parameters are used as input to predict the performance of the retaining system. Sensitivity analysis shall be carried out to evaluate the effects of these parameter variations within a reasonable range on strut force, retaining wall deflection, and bending moment.

\section{Introduction}

Deep excavation supported by vertical retaining walls together with the strutting system is commonly used in Singapore for the construction of underground infrastructure. The widely used retaining wall types in Singapore are sheet pile, soldier pile with timber/sheet pile lagging, contiguous bored piles (CBP), secant bored piles (SBP), and diaphragm walls [1-4]. The excavation will induce lateral wall deflection [5] and vertical ground surface settlement which have negative impact on the nearby structures [6]. According to Singapore regulation [7], the allowable maximum wall deflection shall be less than $0.5 \%-$ $1 \%$ of the excavation depth depending on the geotechnical condition and nearby structures.

There are four main types of geological materials in Singapore [8]: (a) Bukit Timah granite, (b) the sedimentary rocks [9-11], (c) old alluvium (OA), and (d) Kallang formation. The OA is about 2 to 7 million years old and extends from southern Johor to the east of Singapore [12]. The thickness of this formation is generally very high and has been proved to a depth up to $195 \mathrm{~m}$. The OA varies in its weathering degree from fully weathered at the top to unweathered at the bottom. The soil profile above the OA layer mainly consists deep deposit of soft marine clay overlain by a layer of reclamation fill.

At some areas, it was found that the reclaimed fill had been compacted to achieve a minimum relative density of $70 \%$ and the marine clay layer was in an over-consolidated stage. At such areas, the retaining wall installation (sheet pile or soldier pile) may become very difficult and pre-auger drilling is often used to loosen the soil for the installation. However, few scholars have systematically analysed the preauger loosen effect on the retaining wall performance [13].

According to the study by Shirlaw et al. [14], the base heave failure mode will occur when the clay with low shear strength is below the final excavation level directly and the retaining walls are not within the stiff soil layers. Therefore, the retaining walls are required to extend into $\mathrm{OA}$ formation at the current practice in Singapore. However, the effect of embedded length into $\mathrm{OA}$ on the performance of the retaining system is not understood very well by designers. At the same time, in order to effectively control wall movement and associated ground movement, the ground improvement 
layer (GIW) is proposed at the base of the excavation in area where there is a significant depth of clay below the final excavation level [15-18]. For ground improvement in Singapore, the common practice in general is that the test results from all the samples during the construction stage will be higher than the design values. Most designers consider that the higher strength and stiffness of the ground improvement layer do not have any negative impact on the retaining wall system which needs further study in detail.

A parametric sensitivity study is carried out using finiteelement modelling in the software PLAXIS 2D based on an actual project that we were involved in. The effects of preaugering, embedment depth of retaining wall into OA formation, and strength of the ground improvement layer are studied in order to obtain an in-depth understanding of retaining wall design for deep excavation.

\section{Case Study}

2.1. Background. One actual project was studied which is located at the eastern part of Singapore. Typical soil profile consisted of $5 \mathrm{~m}$ to $15 \mathrm{~m}$ thick of sand fill, $5 \mathrm{~m}$ to $25 \mathrm{~m}$ thick of marine clay, and competent $\mathrm{OA}$ of varying weathering degree. Excavation was $35 \mathrm{~m}$ wide and $8.5 \mathrm{~m}$ to $16.7 \mathrm{~m}$ deep. With the consideration of existing site conditions, soldier pile wall and sheet pile lagging was proposed as temporary retaining wall with the laced strutting system. The retaining wall toe embedment criteria were that the soldier pile is to be embedded $3 \mathrm{~m}$ into OA formation. The construction method was bottom-up construction. According to the geology information, the excavation depth, and permanent structure, the whole site was classified into 13 typical excavation zones. A typical section with a depth of $10 \mathrm{~m}$ was studied in this paper. There were 3 layers of steel struts with $6 \mathrm{~m}$ spacing horizontally and $3 \mathrm{~m}$ spacing vertically. In order to effectively control wall movement and associated ground movement, a ground improvement slab of $3 \mathrm{~m}$ thick was proposed at the base of the excavation in area where there was a significant depth of marine clay below the final excavation level. The ground improvement slab was installed prior to excavation. Three rows of permanent bored piles with $1.5 \mathrm{~m}$ diameter piles at the centre row and $1.2 \mathrm{~m}$ diameter at the side rows were designed to support the permanent structure. The bored piles were at $6 \mathrm{~m}$ centre to centre along the longitudinal direction and were embedded into the OA layer. The bored piles and ground improvement layer worked together with retaining wall and steel struts as a robust earth retaining system. The summary of earth retaining wall system and their structural properties used in the analysis were shown in Table 1.

2.2. Finite-Element Modelling. The finite-element method offers the designer an analytical tool that can simulate the complex facets of the earth retaining structures except unquantifiable variables such as workmanship or geological uncertainties. It has the ability to predict both earth pressures and deformations with very minimal simplifying assumptions required. Both structure and soil are considered interactively so that the effects of structural flexibility are taken into account. The commonly used commercial software in Singapore for finite-element modelling in geotechnical engineering is PLAXIS.

The excavation length of this project was $469 \mathrm{~m}$ which is 13.4 times the excavation width. Therefore, the $2 \mathrm{D}$ model was adopted based on the assumption of plane strain condition. To simulate discontinuous wall elements, such as soldier piles, the stiffness in the PLAXIS model was represented on a 'unit' length basis and the contribution of sheet pile lagging was not considered in the analysis. The boundary conditions were as follows.

The lower boundary has zero displacement at both the horizontal and vertical direction. The left and right vertical boundaries were only free at vertical direction, and the upper boundary was free from any direction.

Because the Mohr-Coulomb model (MC) may produce unrealistic soil behaviour [19], the hardening soil (HS) model became more popular in deep excavation analysis in Singapore which can generate more realistic soil response $[20,21]$. The HS model was used in this study and the soil parameters in Table 2 were from the back analysis of similar geotechnical conditions in Singapore [15]. Fill layer was modelled as drained, and marine clay and old alluvium were modelled using the undrained B method.

Several ground improvement methods can be used to improve the properties of the soft ground such as wet speed mixing (WSM), deep cement mixing (DCM), and jet grouting pile (JGP). For this project, DCM was carried out as the main ground improvement method and the $1 \mathrm{~m}$ gap between DCM and the retaining wall was sealed by JGP. Quality of the DCM and JGP was confirmed by carrying out soil investigation boreholes and testing. There were 4 numbers of boreholes for each 1000 cubic meters of the treated soil. Unconfined compression tests on the coring samples were carried out to obtain the undrained strength $\mathrm{Cu}$ and elastic modulus $E$. The test results show that the ratio between elastic modulus $E$ and undrained strength $\mathrm{Cu}$ mainly varies from 300 to 500 when $\mathrm{Cu}$ is less than $1200 \mathrm{kPa}$ (Figure 1). In this project, the design values of $E$ and $\mathrm{Cu}$ are $140 \mathrm{MPa}$ and $300 \mathrm{kPa}$, respectively.

The construction sequence is modelled as follows: (1) initial condition, (2) activate the uniform load $20 \mathrm{kPa}$ for $20 \mathrm{~m}$ length away from retaining wall at ground level of $2.5 \mathrm{mSHD}$ to consider the surcharge load, (3) activate retaining wall and set ground improvement layer at the base of the excavation and activate bored piles, (4) excavate to $1 \mathrm{~m}$ below strut $S 1$ which is at $2 \mathrm{mSHD}$ and install strut $S 1$ and apply preloading of $600 \mathrm{kN},(5)$ excavate to $1 \mathrm{~m}$ below strut $S 2$ which is at $-1 \mathrm{mSHD}$ and install strut $S 2$ and apply preloading of $1200 \mathrm{kN}$, (6) excavate to $1 \mathrm{~m}$ below strut $S 3$ which is at $-4 \mathrm{mSHD}$ and install strut $S 3$ and apply preloading of $1500 \mathrm{kN}$, and (7) excavate to final excavation level (FEL) at $-7.5 \mathrm{mSHD}$. The construction of permanent structure, removal of struts, and backfill are not presented in this paper because the maximum wall deflection, wall bending moment, and strut force occur during the excavation stage for this project. 
TABLE 1: Earth retaining wall system and their structural properties.

\begin{tabular}{|c|c|c|c|}
\hline Type & Size & $\mathrm{EA}(\mathrm{kN})$ & $\mathrm{EI}\left(\mathrm{kNm}^{2} / \mathrm{m}\right)$ \\
\hline Retaining wall & UB $762 \times 267 \times 147 \mathrm{~kg} / \mathrm{m} @ 1.8 \mathrm{~m} \mathrm{c} / \mathrm{c}+$ hat-type sheet pile $10 \mathrm{H}$ & - & $1.97 e^{5}$ \\
\hline Strut $S 1$ at level 1 & $2 \times U B \quad 610 \times 229 \times 125 \mathrm{~kg} / \mathrm{m}$ & $6.64 e^{6}$ & - \\
\hline Strut $S 2$ at level 2 & $2 \times$ UB $610 \times 229 \times 155 \mathrm{~kg} / \mathrm{m}$ & $8.32 e^{6}$ & - \\
\hline Strut $S 3$ at level 3 & $2 \times$ UB $610 \times 229 \times 195 \mathrm{~kg} / \mathrm{m}$ & $7.98 e^{6}$ & - \\
\hline Bored pile at centre ( $30 \mathrm{~m}$ into $\mathrm{OA})$ & $1.5 \mathrm{~m}$ diameter & $2.35 e^{7}$ & $3.31 e^{6}$ \\
\hline Bored pile at side $(20 \mathrm{~m}$ into $\mathrm{OA})$ & $1.2 \mathrm{~m}$ diameter & $1.75 e^{7}$ & $1.36 e^{6}$ \\
\hline
\end{tabular}

TABLE 2: HS soil parameters based on the back analysis of similar geotechnical conditions [15].

\begin{tabular}{lcccccccc}
\hline Soil type & Model & $\begin{array}{c}\gamma(\mathrm{kN} / \\
\mathrm{m})\end{array}$ & $\begin{array}{c}\text { Poisson's ratio } \\
\left(v_{u r}\right)\end{array}$ & $\begin{array}{c}E_{50, \mathrm{ref}}(\mathrm{kN} / \\
\left.\mathrm{m}^{2}\right)\end{array}$ & $\begin{array}{c}\mathrm{E}_{\text {ode, ref }}(\mathrm{kN} / \\
\left.\mathrm{m}^{2}\right)\end{array}$ & $\begin{array}{c}\mathrm{E}_{\mathrm{ur}, \mathrm{ref}}(\mathrm{kN} / \\
\left.\mathrm{m}^{2}\right)\end{array}$ & $\begin{array}{c}\mathrm{c}_{\mathrm{ref}}\left(\mathrm{kN} / \mathrm{m}^{2}\right) / \mathrm{Cu} \\
\left(\mathrm{kN} / \mathrm{m}^{2}\right)\end{array}$ & $\begin{array}{c}\Phi\left({ }^{\circ}\right) \\
\text { Power } m\end{array}$ \\
\hline $\begin{array}{l}\text { Fill } \\
\begin{array}{l}\text { Marine } \\
\text { clay }\end{array}\end{array}$ & Drained & 20 & 0.15 & 1000 & 1300 & 3000 & 0.1 & 25 \\
OA & Undrained & 16 & 0.2 & 3740 & 3740 & 11220 & 0.5 \\
\hline
\end{tabular}

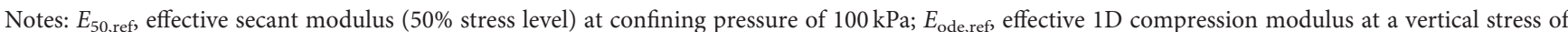
$100 \mathrm{kPa} ; E_{\mathrm{ur}, \text { ref }}$, effective unloading-reloading modulus at a confining pressure of $100 \mathrm{kPa} ; m$, modulus exponent controlling the stress dependency of the modulus.

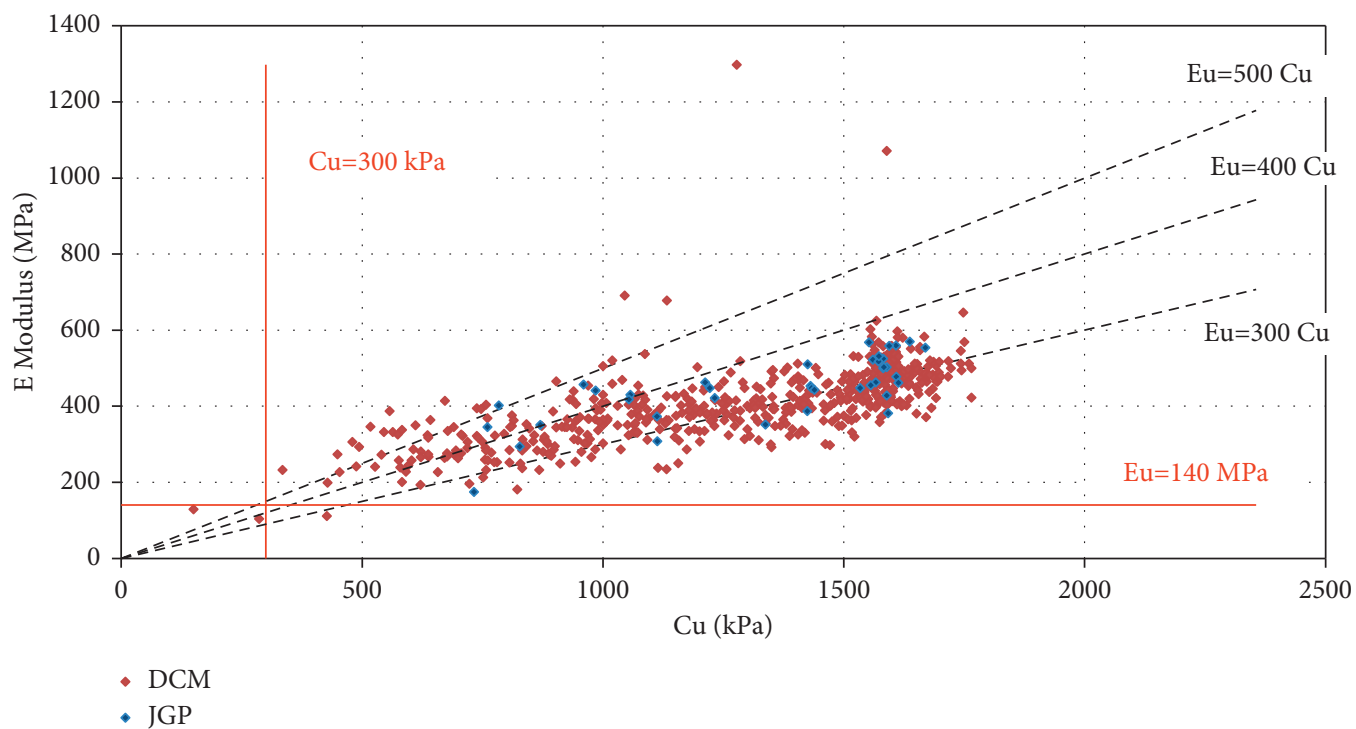

FIGURE 1: Relation between elastic stiffness and undrain strength of the ground improvement layer from coring samples.

The ground water level outside excavation is assumed at the ground level, and the ground water level within excavation will follow the level of each excavation stage, and the water pressure distribution is calculated in each step using the steady stage groundwater flow model.

The modelling area is $200 \mathrm{~m}$ in width and $80 \mathrm{~m}$ in depth, as shown in Figure 2, which is large enough to minimize the boundary effect on the simulation results.

To validate the numerical model, the wall deflection from numerical simulation was compared with the in-field monitoring results which were obtained from inclinometer readings (Figure 3). When the excavation level was $1 \mathrm{~m}$ below $S 2$ strut, the maximum monitoring wall deflection was $14 \mathrm{~mm}$ and the maximum FE predicted wall deflection is $18 \mathrm{~mm}$. These minor differences were accepted and the numerical model can be used for the parametric sensitivity study.

\section{Parametric Sensitivity Study}

3.1. Effect of Pre-Augering. At some areas, the reclaimed fill had been compacted and the marine clay layer was in an over-consolidated stage. And the retaining wall installation (sheet pile or soldier pile) became very difficult, and preauger drilling (Figure 4) was proposed to loosen the soil for the installation. The effect of pre-augering on the surrounding soil loosening shall be studied in detail below.

In PLAXIS 2D, active and passive earth pressures against the retaining walls are not input explicitly but are automatically generated in the program as a consequence of the changes of stress distribution in the finite-element mesh. Related to the wall lateral pressures, the wall adhesion is a factor of the soil strength and is defined in the model using Rinter. For clay, the suggested Rinter is 0.5 to account for 


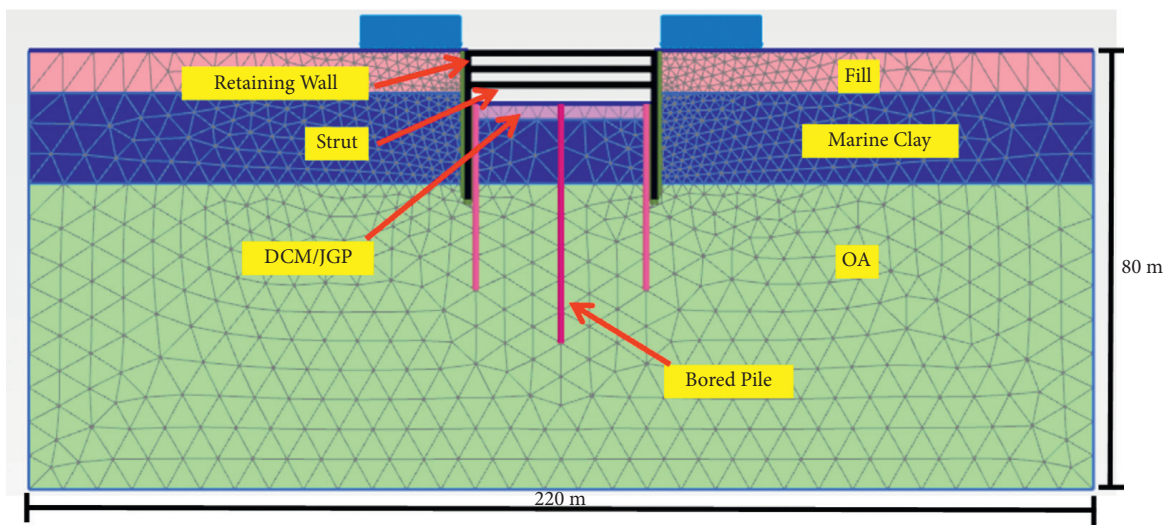

FIgURE 2: FEM mesh used in PLAXIS analysis.

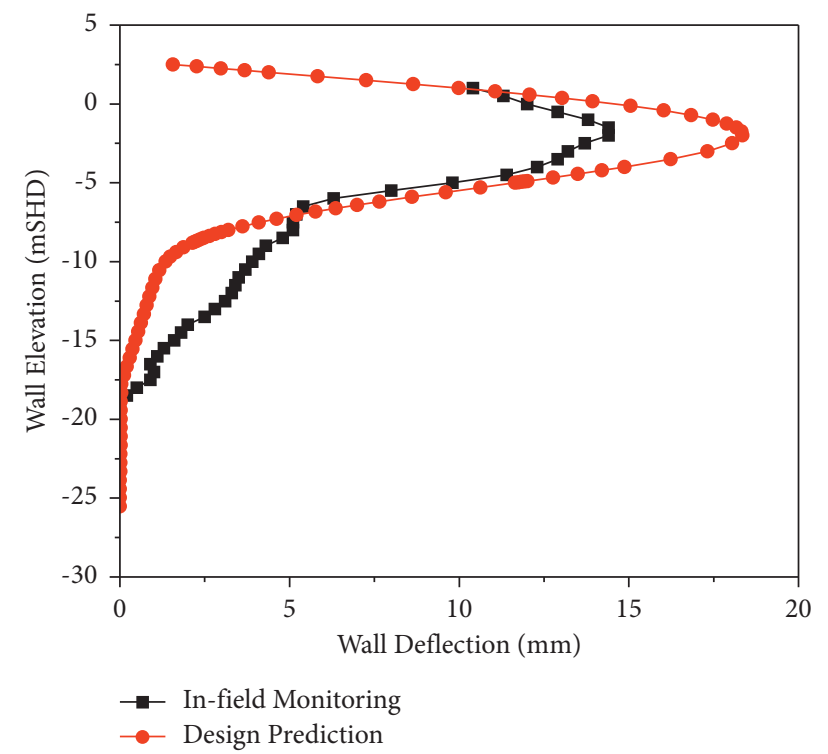

FIgURE 3: Observed and predicted wall deflection (excavation $1 \mathrm{~m}$ below strut S2).

high wall-soil slip compared to sands, where Rinter is generally taken as 0.67 [22]. In order to consider the loosening effect of pre-auger, a new reduction $k$ with range between 0 and 1 is used and the overall wall adhesion is $k \times$ Rinter. The lower bound value of $k=0$ means there is practically no friction between the retaining walls which is the extreme condition of pre-auger [13], and the upper bound value of $k=1$ means there is no loosening effect of pre-auger.

To evaluate the effects of pre-auguring on the retaining wall system, five cases with different $k$ values were simulated. In cases $1-5$, the $k$ values were $1,0.8,0.6,0.4$, and 0.2 , respectively. Figure 5 shows the relations of between different $k$ values and wall deflection when the excavation reaches the final excavation level. Figure 5 illustrates that the soft marine clay below the final excavation level cannot provide sufficient horizontal restraint of the retaining wall, and the maximum wall deflection usually occurs below the final excavation level and the maximum wall deflection increases as $k$ value decreases. The maximum wall deflection only increases from $50 \mathrm{~mm}$ to $55 \mathrm{~mm}$ when $k$ value decreases from 1 to 0.4 . However, the maximum wall deflection increases abruptly from $55 \mathrm{~mm}$ to $68 \mathrm{~mm}$ when $k$ value decreases from 0.4 to 0.2 . Figure 6 presents the relations between different $k$ values and the wall bending moment, and the similar trend demonstrates that the maximum bending moment increases from $388 \mathrm{kNm} / \mathrm{m}$ to $343 \mathrm{kNm} / \mathrm{m}$ and from $343 \mathrm{kNm} / \mathrm{m}$ to $488 \mathrm{kNm} / \mathrm{m}$ when $k$ value decreases from 1 to 0.4 and from 0.4 to 0.2 , respectively. Clearly, the pre-auger loosening effect only has considerable effect when the wall adhesion is very low. The pre-augering effect on the maximum strut force is also studied, as shown in Figure 7 , and it indicates that there is insignificant impact on the strut force.

Therefore, the pre-augering loosening effect on the retaining wall is not significant if the wall adhesion does not reduce too much. In order to minimize the pre-augering effect, the pre-auger should be carried out on the excavation side of the retaining wall and before the ground improvement work so that the subsequent ground improvement work would almost cancel the effect of pre-augering. At the same time, the auger flights were rotated into the ground in 


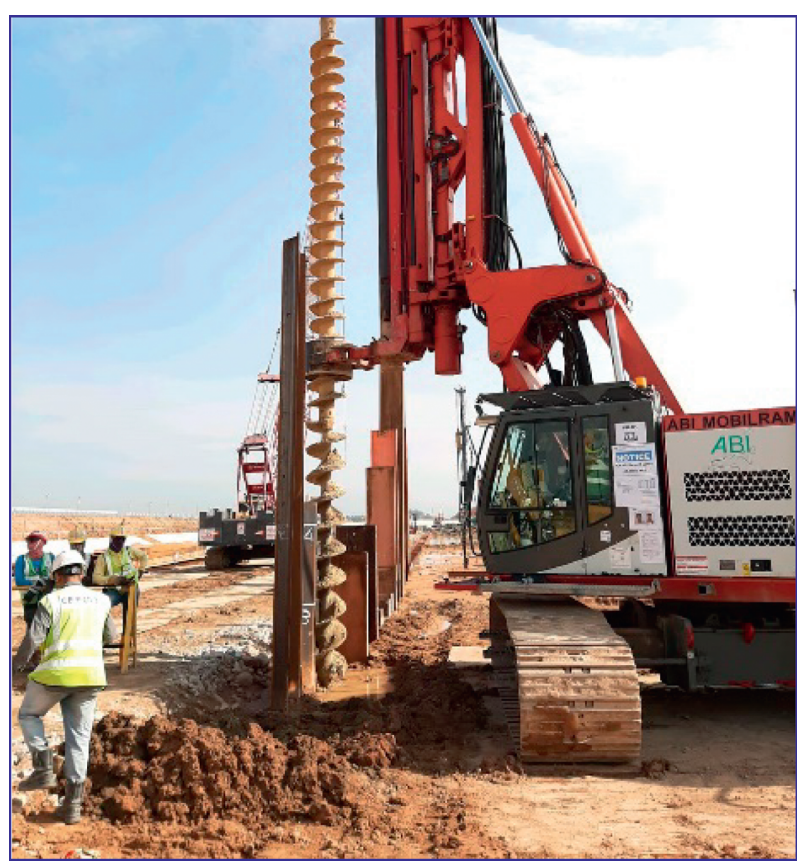

Figure 4: Pre-auguring process to loosen soil for retaining wall installation.

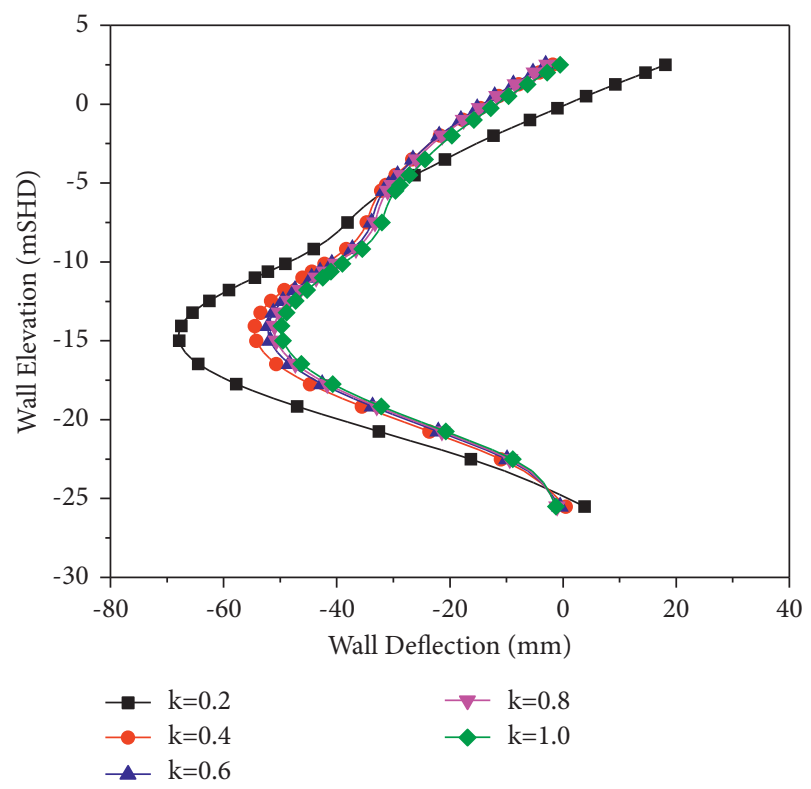

FIGURE 5: The relations between pre-augering loosening effect and wall deflections at the excavation to the FEL stage.

one direction and removed from the ground by rotating in a counter direction leaving the sheared soil in place in the ground.

3.2. Effect of Retaining Wall Embedded Length. To evaluate the effects of the wall embedded depth in OA on retaining wall system, six cases with different wall embedded lengths into OA $(-1,0,1,2,3,4$, and $5 \mathrm{~m})$ were simulated. As shown in Figure 8, the wall deflection above the soffit of the ground

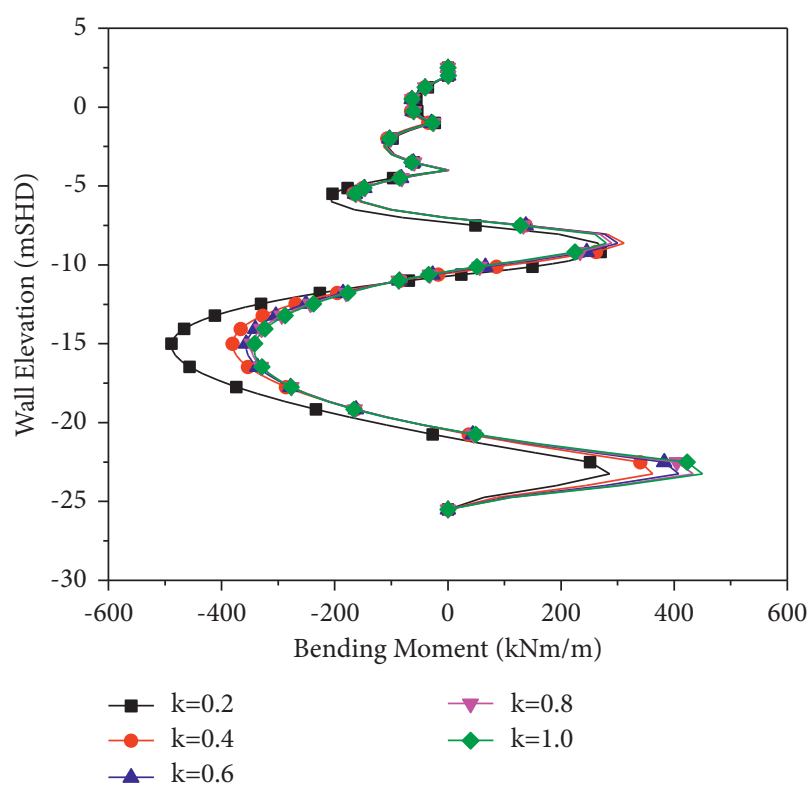

Figure 6: The relations between pre-augering loosening effect and wall bending moment at the excavation to the FEL stage.

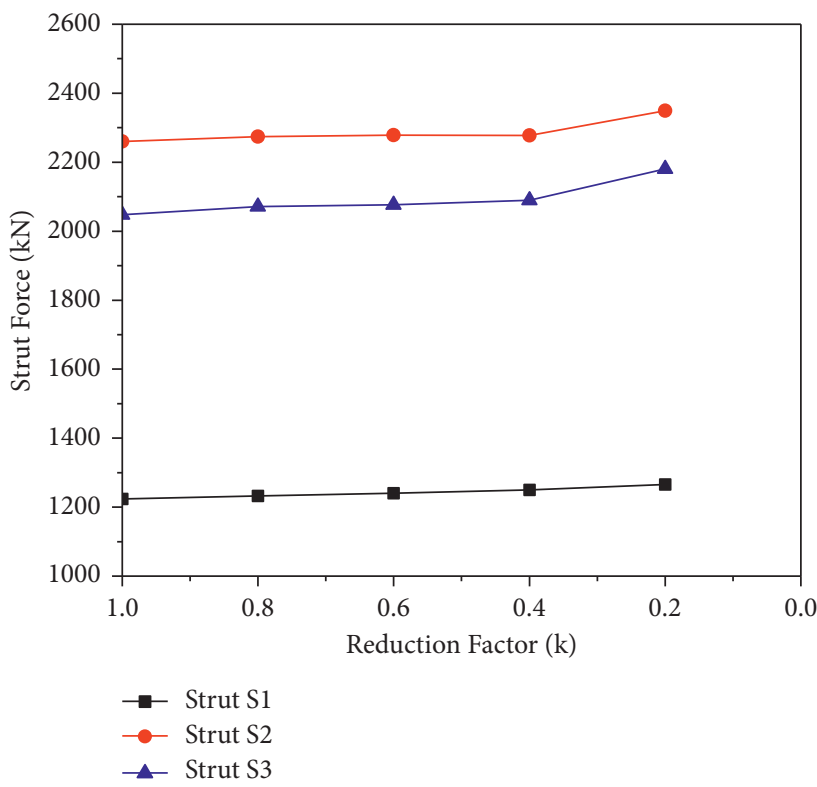

FIGURE 7: The relations between pre-augering loosening effect and the maximum strut forces.

improvement layer was almost identical. However, the wall deflection at the retaining toe reduced from $38 \mathrm{~mm}$ to $0 \mathrm{~mm}$ when the embedded length increased from $-1 \mathrm{~m}$ to $1 \mathrm{~m}$. Figure 9 illustrates the effect of embedded length into OA on the wall bending moment envelop for the whole excavation process. The bending moments within the marine clay and the OA layer increased as the embedded length into OA increased and the bending moment above the soffit of the ground improvement layer was unaffected. Therefore, the increase of embedded length into OA only has impact on the 


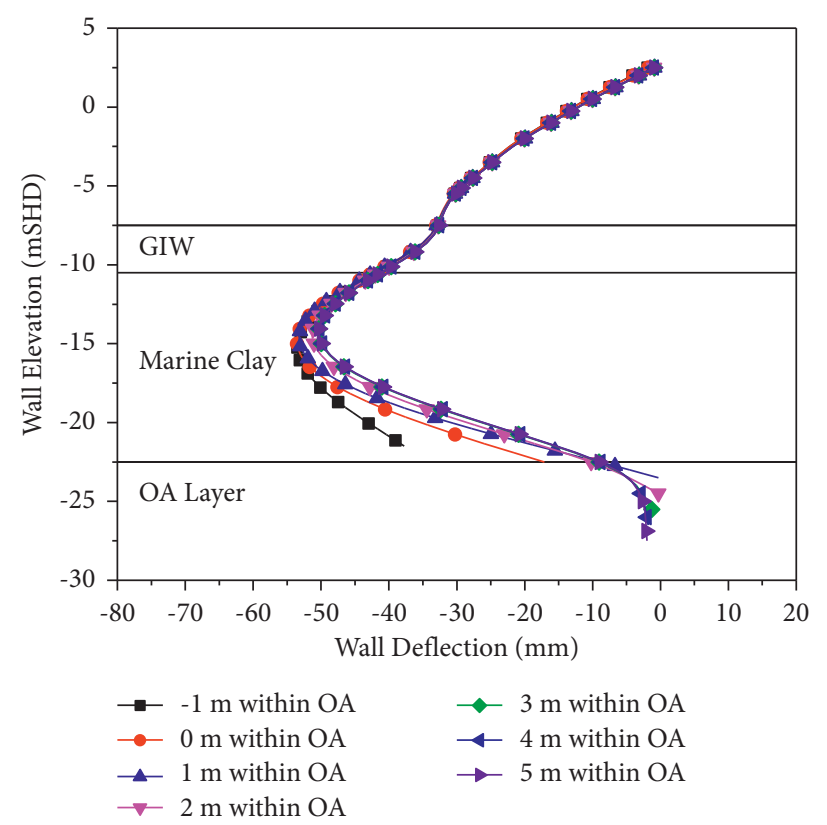

Figure 8: The effect of retaining wall embedded length into OA on wall deflection.

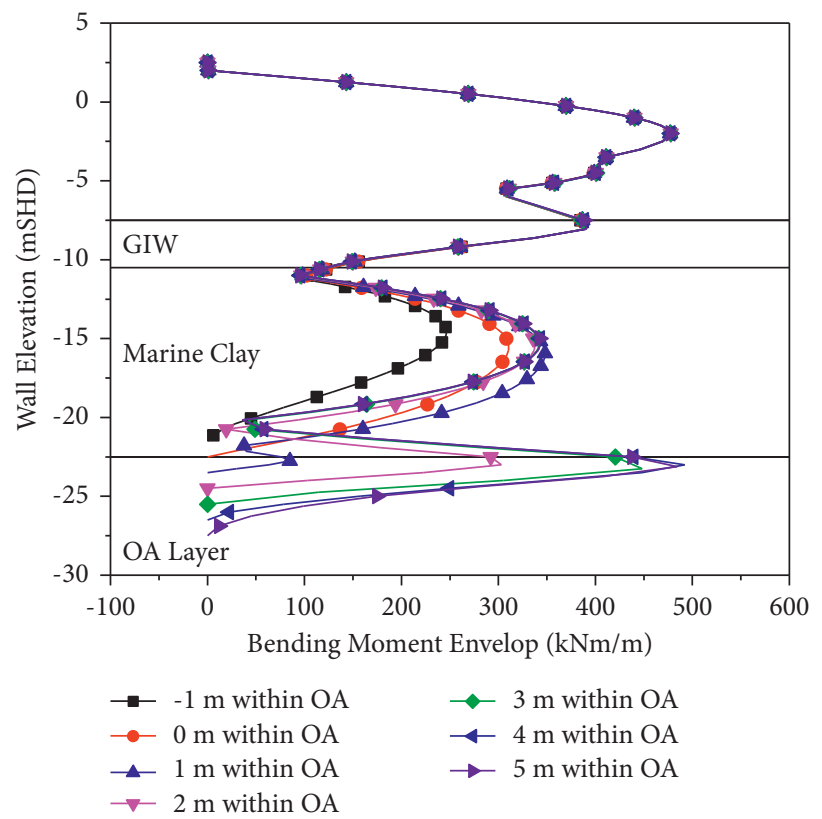

FIgURE 9: The effect of retaining wall embedded length into OA on wall bending moment.

retaining wall below the soffit of the ground improvement layers. Although the bending moment increases at some locations below the soffit of the ground improvement layer, it still is less than the maximum bending moment which is above the final elevation level except the case with the embedded length of $5 \mathrm{~m}$. Therefore, the retaining wall section does not need to be increased for most cases.

On the contrary, when the embedded length was increased, the bending and tension forces of the bored pile were reduced. However, the effect became minor when the embedded length was larger than $3 \mathrm{~m}$, as illustrated in Figures 10-12.
In brief, if a retaining system includes a ground improvement layer, the retaining wall can be embedded $2-3 \mathrm{~m}$ into the stiff soil layer, and extra depth will not reduce the wall deflection and bored pile forces.

3.3. Effect of Ground Improvement Layer. The ground improvement layer was modelled as the Mohr-Coulomb model (undrained B). The elastic modulus Eu varied from 120 to $600 \mathrm{MPa}$, as listed in Table 3. The wall deflection and the bending moment are shown in Figures 13-15 for different Eu values. 


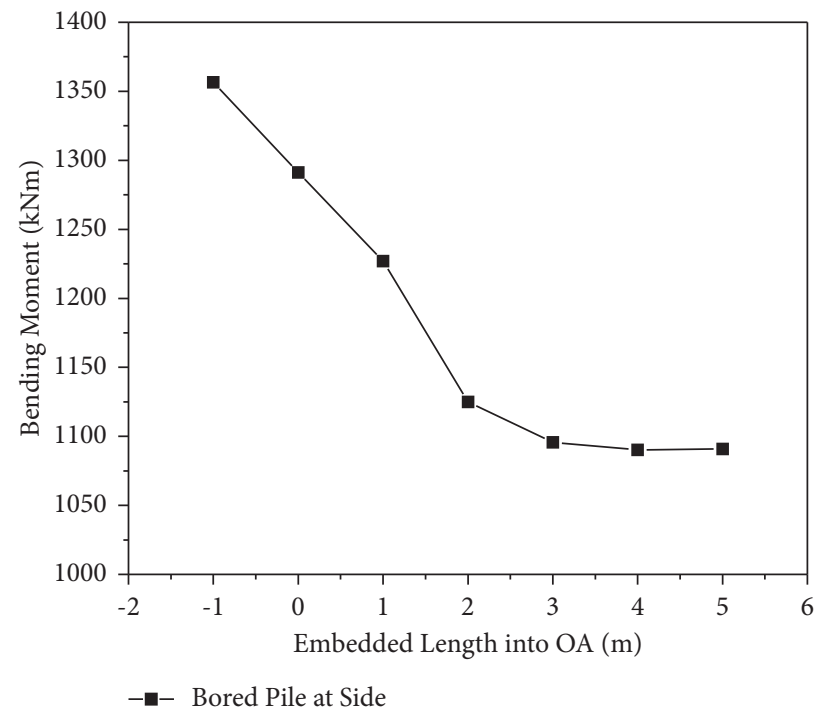

Figure 10: The effect of retaining wall embedded length into OA on bending moment of bore pile at side.

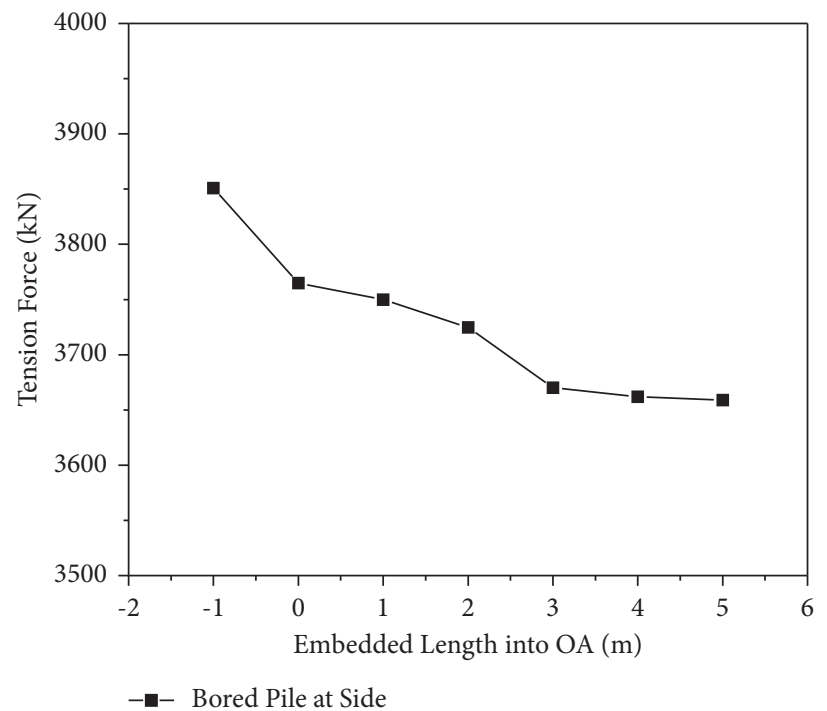

FIgURE 11: The effect of retaining wall embedded length into OA on tension force of bore pile at side.

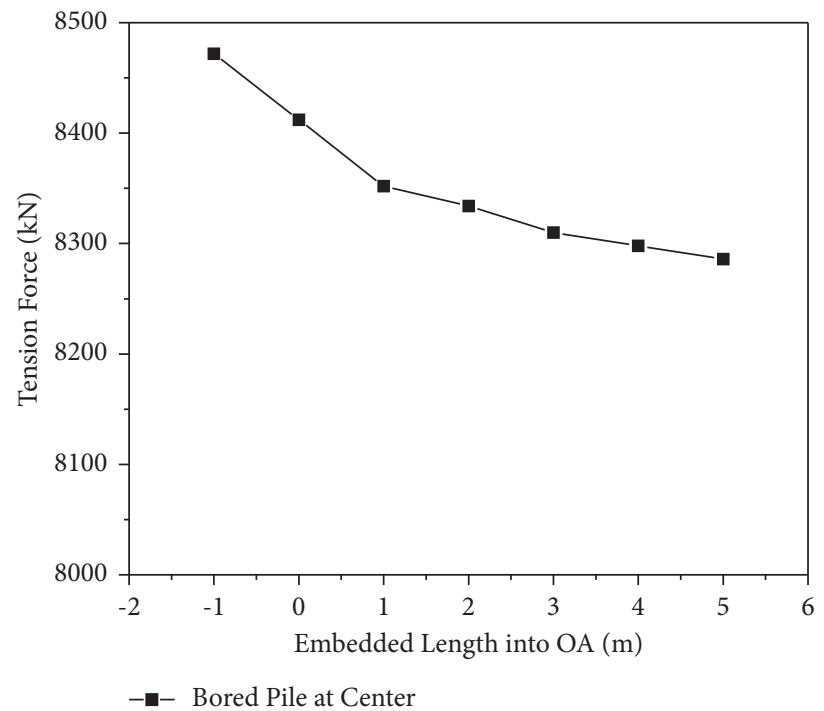

FIgURE 12: The effect of retaining wall embedded length into OA on tension force of bore pile at centre. 
TABLE 3: Ground improvement layer parameters.

\begin{tabular}{|c|c|c|c|c|c|}
\hline Case & Model & $\gamma\left(\mathrm{kN} / \mathrm{m}^{3}\right)$ & Poisson's ratio $\left(v_{u r}\right)$ & $\mathrm{Eu}(\mathrm{MPa})$ & $\mathrm{Cu}(\mathrm{kPa})$ \\
\hline Case 1 & & & 0.3 & 120 & 300 \\
\hline Case 2 & & & 0.3 & 240 & 600 \\
\hline Case 3 & Mohr-Coulomb & 16 & 0.3 & 360 & 900 \\
\hline Case 4 & & & 0.3 & 480 & 1200 \\
\hline Case 5 & & & 0.3 & 600 & 1500 \\
\hline
\end{tabular}

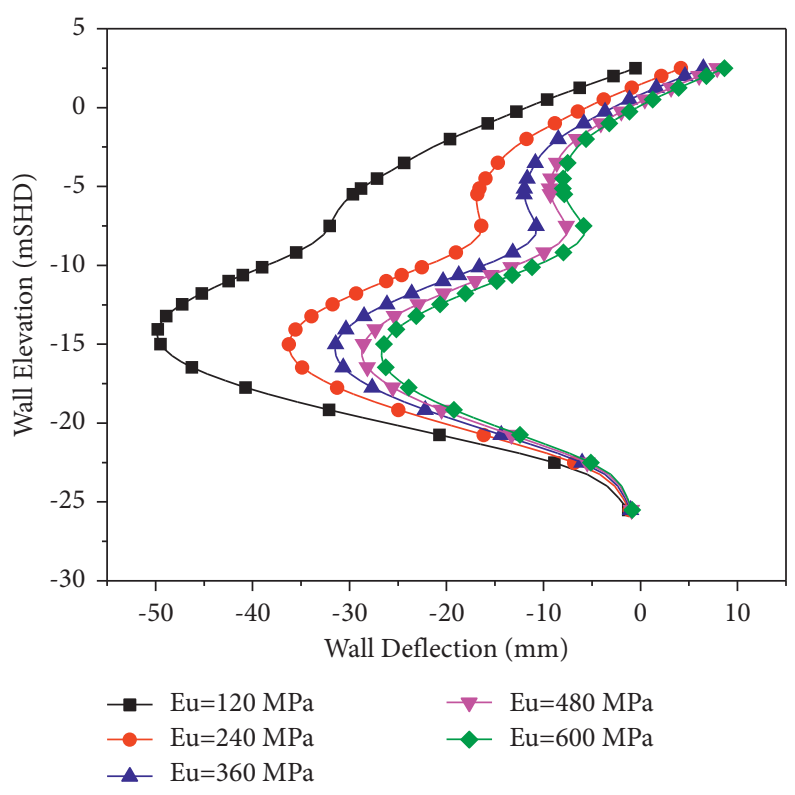

FIgURE 13: The effect of ground improvement Eu on wall deflection.

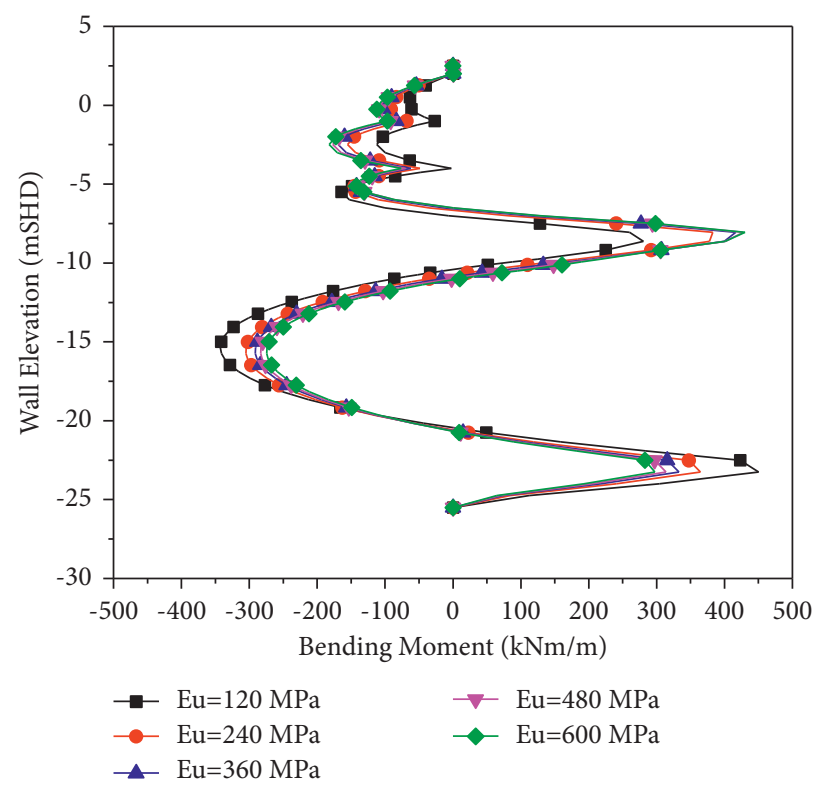

FIGURE 14: The effect of ground improvement Eu on wall bending moment. 


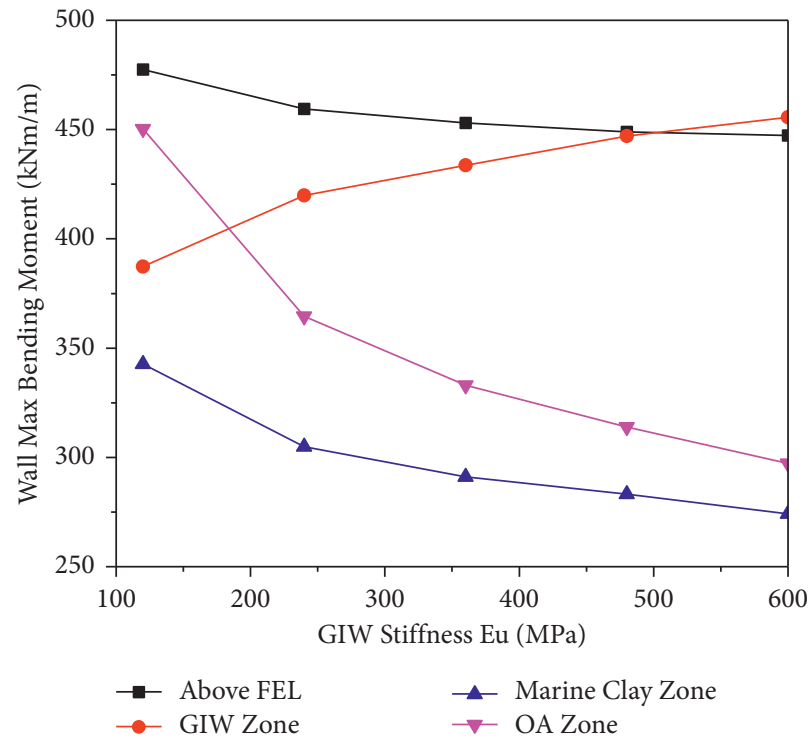

FIgURE 15: The effect of ground improvement $\mathrm{Eu}$ on maximum wall bending moment.

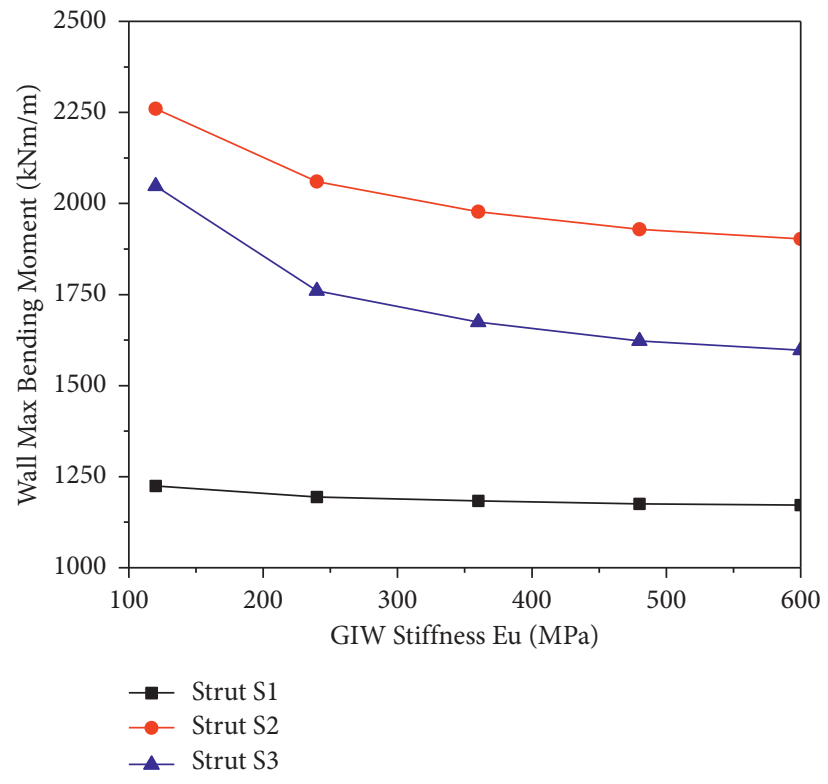

Figure 16: The effect of ground improvement Eu on strut force.

Clearly, the elastic modulus of the ground improvement layer had a significant impact on the support system. When the elastic modulus increased, the wall deflection decreased rapidly, as shown in Figure 13. The wall bending moment at the ground improvement layer increased as Eu increased and the wall bending moment at other area decreased, as illustrated in Figures 14 and 15. Therefore, it is recommended that the design of retaining wall with the ground improvement layer should consider both the lower and upper bound of $\mathrm{Eu}$ at the ground improvement layer because the wall may be under designed. The effect of Eu on the strut forces was demonstrated in Figure 16, and it showed that the strut force near the ground improvement layer had more reduction compared with the struts at the shallower level.

The horizontal compressive stress of the ground improvement layer at the retaining wall interface area is shown in Figure 17. The maximum compressive stress located at the top part of the ground improvement layer which indicated that the possible failure model would start from that zone. Therefore, more attention should be paid to test results of the samples from the top of the coring. 


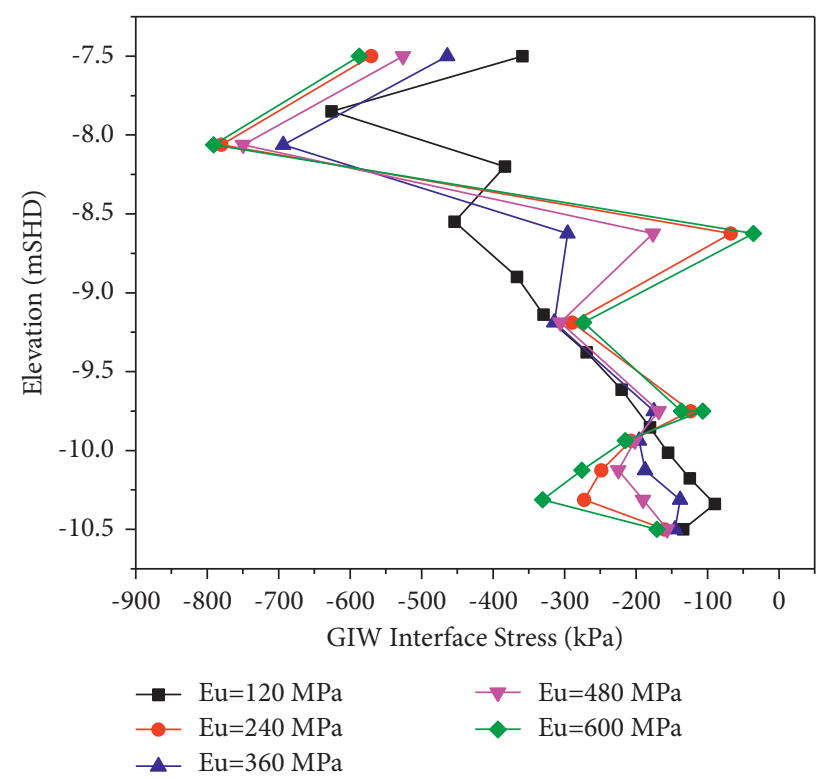

Figure 17: The effect of ground improvement Eu on GIW interface stress.

\section{Conclusions}

Based on a series of numerical simulations for an actual project in Singapore, the key findings are listed as below:

(1) The pre-auger will loosen the surrounding soil of the retaining wall and the wall deflection, and bending moments increase as the wall adhesion reduces. However, the pre-augering loosening effect on the retaining wall is not significant if the wall adhesion does not reduce too much.

(2) The retaining wall-embedded length into OA has contribution to reduce the wall toe movement and has positive impact to reduce the forces on the bored piles. Therefore, soldier pile walls are recommended to be 2-3 $\mathrm{m}$ within the OA layer.

(3) The retaining wall bending moment at the ground improvement layer increases and the forces in struts located below the ground improvement layer decreases as elastic modulus of the ground improvement layer increases.

(4) Based on the above parametric sensitivity analysis, there is high risk if only a single set of parameters are used as input to predict the performance of the retaining system. Sensitivity analysis shall be carried out to evaluate the effects of these parameter variations within a reasonable range on strut force, retaining wall deflection, and bending moment.

\section{Data Availability}

The data used to support the findings of the study are available from the corresponding author upon reasonable request.

\section{Conflicts of Interest}

The authors declare that they have no conflicts of interest.

\section{References}

[1] C. Murugamoorthy, C. M. Kho, B. G. Vaidya, S. K. Tang, and T. Subramanian, "Behaviour of various support systems for deep excavations, changi airport underground MRT station," in Proceedings of the RTS Conference, Singapore, 2003.

[2] H. O. Nick, B. S. Carlus, P. R. Prabhakara, and J. B. Vontivilu, A Review of the Performance of Little India Station during Construction, Underground Singapore, Singapore, 2014.

[3] C. Zhu, M. C. He, X. H. Zhang, Z. G. Tao, Q. Yin, and L. F. Li, "Nonlinear mechanical model of constant resistance and large deformation bolt and influence parameters analysis of constant resistance behavior," Rock and Soil Mechanics, vol. 42, no. 7, pp. 1911-1924, 2021.

[4] Y. H. S. Low, C. C. D Ng, Y. P. Y. Chin, and S. K. E. Ting, "A Singapore case history of temporary removable ground anchor design to TR26: 2010," The IES Journal Part A: Civil \& Structural Engineering, vol. 5, no. 3, pp. 181-194, 2012.

[5] A. T. C. Goh, F. Zhang, W. Zhang, Y. Zhang, and H. Liu, "A simple estimation model for $3 \mathrm{D}$ braced excavation wall deflection," Computers and Geotechnics, vol. 83, pp. 106-113, 2017.

[6] P. Fok, B. H. Neo, K. H. Goh, and D. Wen, "Assessing the impact of excavation-induced movements on adjacent buildings," The IES Journal Part A: Civil \& Structural Engineering, vol. 5, no. 3, pp. 195-203, 2012.

[7] K. S. Yang, Advisory Note 1/09 on Earth Retaining or Stabilizing Structures (ERSS), Building and Construction Authority, Singapore, 2009.

[8] J. S. Sharma, J. Chu, and J. Zhao, "Geological and geotechnical features of Singapore: an overview," Tunnelling and Underground Space Technology, vol. 14, no. 4, pp. 419-431, 1999. 
[9] Q. Yin, J. Wu, C. Zhu, M. He, Q. Meng, and H. Jing, "Shear mechanical responses of sandstone exposed to high temperature under constant normal stiffness boundary conditions," Geomechanics and Geophysics for Geo-Energy and Geo-Resources, vol. 7, no. 2, p. 35, 2021.

[10] X. Li, K. Peng, J. Peng, and H. Xu, "Effect of cyclic wettingdrying treatment on strength and failure behavior of two quartz-rich sandstones under direct shear," Rock Mechanics and Rock Engineering, vol. 54, no. 11, pp. 5953-5960, 2021.

[11] X. S. Li, K. Peng, J. Peng, and D. Hou, "Experimental investigation of cyclic wetting-drying effect on mechanical behavior of a medium-grained sandstone," Engineering Geology, vol. 293, Article ID 106335, 2021.

[12] K. S. Wong, W. Li, J. N. Shirlaw, J. C. W. Ong, D. Wen, and J. C. W. Hsu, "Old alluvium: engineering properties and braced excavation performance," in Proceedings of the Underground Singapore, Singapore, November 2001.

[13] A. Piling, Handbook, ArcelorMittal Commercial RPS UK Ltd, Solihull, UK, 9th edition, 2016.

[14] J. N. Shirlaw, T. S. Tan, and K. S. Wong, "Deep excavations in Singapore marine clay," in Proceedings of the 5th International Conference of TC28 of the ISSMGE, vol. 13-28, Amsterdam, Netherlands, March 2006.

[15] G. J. Li, K. S. Wong, and P. B. Ng, "Back analysis of a braced excavation with DCM ground improvement," in Proceedings of the Underground Singapore, Singapore, January 2011.

[16] G. A. Pittaro and G. Murphy, "Deep Excavation with Ground Improvement- a Study Using Statistics and Back Analysis from a Monitored Excavation," in Proceedings of the Underground Singapore, Singapore, September 2018.

[17] W. Zhang, L. Hong, Y. Li, R. Zhang, A. T. C. Goh, and H. Liu, "Effects of jet grouting slabs on responses for deep braced excavations," Underground Space, vol. 6, 2020.

[18] W. Zhang, Y. Li, A. T. C. Goh, and R. Zhang, "Numerical study of the performance of jet grout piles for braced excavations in soft clay," Computers and Geotechnics, vol. 124, Article ID 103631, 2020.

[19] T. L. Guow, "Common mistakes on the application of Plaxis $2 \mathrm{D}$ in analyzing excavation problems," International Journal of Applied Engineering Research, vol. 9, no. 21, pp. 8291-8311, 2014.

[20] T. Schanz, P. A. Vermeer, and P. G. Bonnier, "The hardening soil model: formulation and verification," Beyond 2000 in computational geotechnics, pp. 281-296, Routledge, Thames, UK, 1999.

[21] P. L. Teo and K. S. Wong, "Application of the hardening soil model in deep excavation analysis," The IES Journal Part A: Civil \& Structural Engineering, vol. 5, no. 3, pp. 152-165, 2012.

[22] A. Gaba, S. Hardy, L. Doughty, W. Powrie, and D. Selematas, Guidance on embedded retaining wall design, Construction Industry Research and Information Association, London, UK, 2017. 